\title{
REINFECTION AND NON TRANSMISSION OF COVID 19- AN UNUSUAL CASE REPORT
}

KEY WORDS:

\section{Dr.Ghantasala Chidember Nath*}

\section{Dr.Abdelsalam} Abuzreda

\section{Dr.Amenh} B.Yousif
MD;DM, GASTROENTEROLOGY CONSULTANT PHYSICIAN ,Arabian Gulf Oil Company(AGOCO),Benghazi, Libya. *Corresponding Author

Postdoctoral Researcher-Assistant Professor at The University of Benghazi and Coordinator of the Department of Health Safety and Environment (HSE), Arabian Gulf Oil Company(AGOCO),Benghazi,Libya.

Lecturer -Department of Family and Community Medicine-Faculty of Medicine, University of Benghazi,Libya

In December 2019, a novel coronavirus, called SARS-CoV-2, caused an acute atypical respiratory disease in Wuhan, China. The disease was termed as COVID-19. The virus is shown to have human transmission and has caused pandemic and panic worldwide. Increasing death tolls have been noted worldwide. Social distancing and lockdown has been enforced worldwide. Lack of targeted therapy continues to be a problem. SARS-CoV-2 RT-PCR re-positivity describes positive RT-PCR following negative tests in an asymptomatic patient up to 90 days from the first episode. Here, we report a case of a 33 year old male patient who was tested positive for COVID and accidentally travelled with 16 other passengers on a bus without transmission of the disease.

\section{INTRODUCTION}

A new form of coronavirus (SARS-CoV-2) started in Wuhan city ofChina in December,2019 spread rapidly worldwide and has resulted in an outbreak of viral pneumonia, termed as Coronavirus disease (COVID-19).The novel coronavirus is synonymous with severe acute respiratory syndrome coronavirus-2 (SARS-CoV-2) due to its equitability $(\sim 80 \%)$ to SARS-CoV, resulting in acute respiratory distress syndrome (ARDS) associated mortality during 2002-2003 (1). The SARSCoV-2 outbreak was considered to have been transmitted through zoonotic transmission tracing to the seafood market in Wuhan, China. However, human transmission played a major role in the subsequent outbreak (2).

SARS-CoV-2 majorly attacks the respiratory system, although other organs are also found to be affected. In cases of a lower respiratory tract infection, patients present with symptoms of dry cough, fever and dyspnea. The lesser common features include headache, dizziness, fatigue, vomiting and diarrhea (3). COVID-19 is now recognized with heterogeneous symptoms includinghypoxia with ARDS. As per the reports from Wuhan, the time from onset of symptoms and the development of ARDS was 9 days, suggesting that the respiratory symptoms can rapidly worsen and may prove fatal. (4). Several thousand people have already succumbed to the disease worldwide with higher mortality rates in the elderly.(5) Children are less commonly affected. $(6,7)$. Current medical management is largely supportive with no targeted therapy available. Several drugs including lopinavir-ritonavir, remdesivir, hydroxychloroquine, and azithromycin have been tested in clinical trials (8), but none of them have been proven to be a definite therapy yet. More therapies are being tested in clinical trials. A large number of countries have implemented social distancing and lockdown to mitigate further spread of the virus. Here, we report a case of a 33 year old male patient who was tested positive for COVID and accidentally travelled with 16 other passengers on a bus without transmission of the disease.

\section{CASE REPORT}

A 33 year old male patient presented with complaints of loss of smell and taste. A nasopharyngeal swab was taken and patient was tested positive for COVID by RT PCR. All baseline blood investigations were normal. Chest X-RAY showed ground glass opacities in the lower lobe of left lung. CTThorax showed CORADS 2.
After 45 days patient was asymptomatic andhe was tested for Antibodies (IgG and Ig M) and also screened for RT PCR. The RT PCR showed positive results which was confirmed by Gene Xpertpositive test.

However, on 45th day, the patient unintentionally travelled with 16 other coworkers traveled for 2 hours in a closed bus. All 16 persons were quarantined for 14 days. All of them where asymptomatic and were tested for antibodies (Rapid IgG and IgM) and their RT PCR on 14 th and 21 st day were negative.

\section{DISCUSSION}

Various articles in literaturehave reported cases of re-positive SARS-CoV-2 PCR following negative results and clinical convalescence, or recurrent symptoms, compatible with COVID-19, along with a positive RT-PCR, in recovering patients. The reported cases were described in a time frame of less than 90 days from the period of acute illness and may be representative of persistent/fluctuant viral shedding with persistent or recurring clinical illness, rather than true reinfection. Other viral infections or bacterial/fungal superinfections may also explain a coinciding symptomatic episode in the presence of remnant SARS-CoV-2 RNA in some of these occurrences (9). In addition, weakly re-positive PCR (cycle threshold $(\mathrm{Ct})$ values $>35$ ) results probably do not reflect true active infection, but rather non-replicating virus(9).

The clinical course of illness among hospitalized COVID-19 patients might be prolonged in patients with severe and critical disease. The median hospitalization duration in a large series from China was reportedly 22 days among survivors, with viral shedding for a median of 20 days and as long as 37 days (10). In other reports, viral shedding from upper respiratory specimens has been detected up to 12 weeks. According to CDC, positive PCR during a 90-day time frame probably represents prolonged shedding rather than reinfection. However, replication-competent virus has only rarely been detected up to 10-20 days, and even then mostly in cases of severe COVID-19, although even longer times have been reported for patients in an immunocompromised state (11).

In addition to prolonged shedding, re-positive PCR tests have been described in $14 \%$ of discharged patients (12). An 
investigation of 285 re-positive cases by the Korean CDC demonstrated neutralizing antibodies in all patients, negative cultures in all 108 tested and Ct values > 30 in 68 (89.5\%) of 76 tests (13).

In our patient, after 45 days inspite of positive results the disease was not transmitted to other individuals. Therefore, careful analysis of viral load is essential to interpret all these studies and to enable comparison between results, they should be expressed in standardized copy numbers not $\mathrm{Ct}$ values.

\section{REFERENCES:}

1. Ksiazek T.G., Erdman D., Goldsmith C.S., Zaki S.R., Peret T., Emery S., Tong S., Urbani C., Comer J.A., Lim W., Rollin P.E., Dowell S.F., Ling A.E., Humphrey C.D., Shieh W.J., Guarner J., Paddock C.D., Rota P., Fields B., DeRisi J.,Yang J.Y., Cox N., Hughes J.M., LeDuc J.W., Bellini W.J., Anderson L.J., SW Group A novel coronavirus associated with severe acute respiratory syndrome. NEnglJMed. 2003;348:1953-1966. [PubMed] [Google Scholar]

2. Li Q., Guan X.,Wu P.,Wang X., Zhou L., TongY., Ren R., Leung K.S.M., Lau E.H.Y., Wong J.Y., Xing X., Xiang N.,WuY., Li C., Chen Q., Li D., Liu T., Zhao J., Liu M.,Tu W., Chen C., Jin L., Yang R.,Wang O., Zhou S., Wang R., Liu H., Luo Y., Liu Y., Shao G., Li H., Tao Z., Yang Y., Deng Z., Liu B., Ma Z., Zhang Y., Shi G., Lam T.T.Y., Wu J.T., Gao G.F., Cowling B.J., Yang B., Leung G.M., Feng Z. Early transmission dynamics in Wuhan, China, of Novel Coronavirus-infected pneumonia. NEngl JMed.2020;382:1 199-1207. [PMC free article] [PubMed] [Google Scholar]

3. Shi H., Han X., Jiang N., CaoY., Alwalid O., Gu J., Fan Y., Zheng C. Radiological findings from 81 patients with COVID-19 pneumonia in Wuhan, China: a descriptive study. Lancet Infect Dis. 2020;20:425-434. [PMC free article] [PubMed] [Google Scholar]

4. Huang C., Wang Y., Li X., Ren L., Zhao J., Hu Y., Zhang L., Fan G., Xu J., Gu X., Cheng Z., Yu T., Xia J., Wei Y., Wu W., Xie X., Yin W., Li H., Liu M., XiaoY., Gao H., Guo L., Xie J., Wang G., Jiang R., Gao Z., Jin Q., Wang J., Cao B. Clinical features of patients infected with 2019 novel coronavirus in Wuhan, China. Lancet. 2020;395:497-506. [PMC free article] [PubMed] [Google Scholar]

5. Zhou F., Yu T., Du R., Fan G., Liu Y., Liu Z., Xiang J., Wang Y., Song B., Gu X., Guan L., WeiY., Li H.,Wu X., Xu J., Tu S., Zhang Y., Chen H., Cao B. Clinical course and risk factors for mortality of adult inpatients with COVID-19 in Wuhan, China: a retrospective cohort study. Lancet. 2020;395:1054-1062. [PMC free article] [PubMed] [Google Scholar]

6. Lu X., Zhang L., Du H., Zhang J., Li Y.Y., Qu J., Zhang W., Wang Y., Bao S., LiY., Wu C., Liu H., Liu D., Shao J., Peng X., Yang Y., Liu Z., Xiang Y., Zhang F., Silva R.M., Pinkerton K.E., Shen K., Xiao H., Xu S., Wong G.W.K., T Chinese Pediatric Novel Coronavirus Study SARS-CoV-2 infection in children. N Engl J Med. 2020 doi: 10.1056/NEJMc2005073. [PMC free article] [PubMed] [CrossRef] [Google Scholar]

7. Qiu H., Wu J., Hong L., Luo Y., Song Q., Chen D. Clinical and epidemiological features of 36 children with coronavirus disease 2019 (COVID-19) in Zhejiang, China: an observational cohort study. Lancet Infect Dis. 2020 doi: 10.1016/S1473-3099(20)30198-5. [PMC free article] [PubMed] [CrossRef] [Google Scholar]

8. Cao B. A trial of Lopinavir-ritonavir in adults hospitalized with severe Covid19. $N$ Engl J Med. 2020 doi: 10.1056/NEJMoa2001282. [PMC free article] [PubMed] [CrossRef] [Google Scholar]

9. Singanayagam A., Patel M., Charlett A., Lopez Bernal J., Saliba V., Ellis J. Duration of infectiousness and correlation with RT-PCR cycle threshold values in cases of COVID-19, England, January to May 2020. Euro Surveill. 2020;25 doi: 10.2807/1560-7917.ES.2020.25.32. 2001483. [PMC free article] [PubMed] [CrossRef] [Google Scholar]

10. Zhou F., Yu T., Du R., Fan G., Liu Y., Liu Z. Clinical course and risk factors for mortality of adult inpatients with COVID-19 in Wuhan, China: a retrospective cohort study. Lancet. 2020;395:1054-1062. [PMC free article] [PubMed] [Google Scholar]

11. CDC . 2020. Duration of isolation and precautions for adults with COVID19.https://www.cdc.gov/coronavirus/2019-ncov/hcp/duration-isolation. html [Google Scholar]

12. Lu J., Peng J., Xiong Q., Liu Z., Lin H., Tan X. Clinical, immunological and virological characterization of COVID-19 patients that test re-positive for SARS-CoV-2 by RT-PCR. EBioMedicine. 2020;59 doi: 10.1016/ j.ebiom. 2020.102960. [PMC free article] [PubMed] [CrossRef] [Google Scholar]

13. Korean CDC . 2020. Findings from investigation and analysis of re-positive cases.http://www.kdca.go.kr/board/board.es?mid=a30402000000\&bid=00 $30 \&$ act $=$ view\&list_no $=367267 \&$ nPage $=24$ [Google Scholar] 